\title{
Maternal Morbid Obesity and Obstetric Outcomes
}

\author{
Nadine Farah Niamh Maher Sinead Barry Mairead Kennelly Bernard Stuart \\ Michael J. Turner \\ UCD School of Medicine and Medical Science, Coombe Women and Infants University Hospital, Dublin, Ireland
}

\author{
Key Words \\ Morbid obesity · Pregnancy
}

\section{Summary}

Objective: The purpose of this retrospective cohort study was to review pregnancy outcomes in morbidly obese women who delivered a baby weighing $500 \mathrm{~g}$ or more in a large tertiary referral university hospital in Europe. Methods: Morbid obesity was defined as a BMI $\geq 40.0 \mathrm{~kg} / \mathrm{m}^{2}$ (WHO). Only women whose BMI was calculated at their first antenatal visit were included. The obstetric outcomes were obtained from the hospital's computerised database. Results: The incidence of morbid obesity was $0.6 \%$ in 5,824 women. Morbidly obese women were older and were more likely to be multigravidas than women with a normal BMI. The pregnancy was complicated by hypertension in $35.8 \%$ and diabetes mellitus in $20.0 \%$ of women. Obstetric interventions were high, with an induction rate of $42.1 \%$ and a caesarean section rate of $45.3 \%$. Conclusions: Our findings show that maternal morbid obesity is associated with an alarmingly high incidence of medical complications and an increased level of obstetric interventions. Consideration should be given to developing specialised antenatal services for morbidly obese women. The results also highlight the need to evaluate the effectiveness of pre-pregnancy interventions in morbidly obese women.

\section{Introduction}

Numerous recent studies have highlighted the increase in pregnancy complications associated with maternal obesity [1]. Internationally, the diagnosis of obesity is based on a $\mathrm{BMI} \geq 30.0 \mathrm{~kg} / \mathrm{m}^{2}$. Based on this classification, the incidence of maternal obesity is increasing, especially in affluent countries. The degrees of obesity may also be classified into I
(BMI 30-34.9 kg/m²), II (BMI 35-39.9 kg/m²) or III (BMI $\geq 40.0 \mathrm{~kg} / \mathrm{m}^{2}$ ). Adults in class III are considered morbidly obese.

There is a paucity of information on clinical outcomes in women who are morbidly obese. The purpose of this study, therefore, was to review the pregnancy outcomes in morbidly obese women who delivered a baby in 2007 in a large tertiary referral university hospital in Europe.

\section{Participants and Methods}

The study was confined to women with singleton pregnancies, who delivered a baby weighing $500 \mathrm{~g}$ or more in the year 2007. There were 8,246 deliveries. Analysis was confined to those who had their BMI calculated, in the first trimester, at their first antenatal visit $(\mathrm{n}=5,824)$. Weight $(\mathrm{kg})$ was measured in light clothing on a standard weighing scale and height (m) was self-reported. Morbid obesity was defined as a BMI $\geq 40.0 \mathrm{~kg} / \mathrm{m}^{2}$ (WHO). Blood pressure was measured using the appropriate cuff size for a designated midarm circumference [2]. Outcome variables included rates of gestational diabetes, preeclampsia, induction of labour, caesarean delivery, operative vaginal delivery and infant birth weight.

All women requiring caesarean delivery received prophylactic antibiotics intra-operatively to prevent infection and prophylactic heparin postnatally to prevent venous thromboembolism according to the hospital guidelines for all caesarean sections $[3,4]$.

The clinical outcomes were obtained from the hospital's computerised database. An individual chart review was undertaken on all the women with morbid obesity to validate the database.

Statistical analysis was carried out using SPSS version 15.0. A one-way analysis of variance (ANOVA) was used to test to evaluate differences in continuous variables across the groups. Chi-square test was used for categorical variables. A p value $<0.05$ was considered significant.

\section{Results}

There were 8,246 women with singleton pregnancies who delivered a baby weighing $500 \mathrm{~g}$ or more in the year 2007. BMI from the first trimester was available on 5,824 women. Of these women, $95(0.6 \%)$ were morbidly obese and 3,146 had

\section{KARGER}

Fax +497614520714

Information@Karger.de

www.karger.com (c) 2009 S. Karger GmbH, Freiburg

Accessible online at:

www.karger.com/ofa 
Table 1. Obstetric outcomes: comparison between the BMI categories

\begin{tabular}{|c|c|c|c|c|c|c|}
\hline & \multicolumn{5}{|l|}{$\mathrm{BMI}, \mathrm{kg} / \mathrm{m}^{2}$} & \multirow[t]{2}{*}{$\mathrm{p}$ value* } \\
\hline & $\begin{array}{l}<18.5 \\
(\mathrm{n}=162)\end{array}$ & $\begin{array}{l}\geq 18.5 \text { and }<25^{*} \\
(\mathrm{n}=3,146)\end{array}$ & $\begin{array}{l}\geq 25 \text { and }<30 \\
(n=1,641)\end{array}$ & $\begin{array}{l}\geq 30 \text { and }<40 \\
(n=780)\end{array}$ & $\begin{array}{l}\geq 40 * \\
(\mathrm{n}=95)\end{array}$ & \\
\hline Mean birth weight, $g$ & $3,235 \pm 450$ & $3,423 \pm 534$ & $3,516 \pm 532$ & $3,584 \pm 600$ & $3,705 \pm 666$ & $<0.001$ \\
\hline Induction rate, $\%$ & $\begin{array}{l}16.0 \\
(n=26)\end{array}$ & $\begin{array}{l}23.5 \\
(\mathrm{n}=740)\end{array}$ & $\begin{array}{l}26.3 \\
(n=432)\end{array}$ & $\begin{array}{l}30.9 \\
(\mathrm{n}=241)\end{array}$ & $\begin{array}{l}42.1 \\
(n=40)\end{array}$ & $<0.001$ \\
\hline Instrumental vaginal delivery rate, $\%$ & $\begin{array}{l}16.0 \\
(n=26)\end{array}$ & $\begin{array}{l}20.0 \\
(n=630)\end{array}$ & $\begin{array}{l}16.5 \\
(n=270)\end{array}$ & $\begin{array}{l}15.9 \\
(n=124)\end{array}$ & $\begin{array}{l}14.7 \\
(n=14)\end{array}$ & $<0.001$ \\
\hline Emergency caesarean section rate, \% & $\begin{array}{l}6.8 \\
(\mathrm{n}=11)\end{array}$ & $\begin{array}{l}8.5 \\
(n=267)\end{array}$ & $\begin{array}{l}10.1 \\
(n=166)\end{array}$ & $\begin{array}{l}13.7 \\
(\mathrm{n}=107)\end{array}$ & $\begin{array}{l}20.0 \\
(n=19)\end{array}$ & $<0.001$ \\
\hline Elective caesarean section rate, \% & $\begin{array}{l}9.3 \\
(n=15)\end{array}$ & $\begin{array}{l}5.9 \\
(\mathrm{n}=186)\end{array}$ & $\begin{array}{l}8.3 \\
(n=137)\end{array}$ & $\begin{array}{l}11.2 \\
(\mathrm{n}=87)\end{array}$ & $\begin{array}{l}25.3 \\
(n=24)\end{array}$ & $<0.001$ \\
\hline
\end{tabular}

*Refers to $\mathrm{p}$ value between the indicated BMI categories.

Table 2. Comparison between BMI categories of obstetric outcomes in women with one previous caesarean section

\begin{tabular}{|c|c|c|c|c|c|c|}
\hline & \multicolumn{5}{|c|}{ BMI, kg/m² } & \multirow[t]{2}{*}{$\mathrm{p}$ value* } \\
\hline & $\begin{array}{l}<18.5 \\
(n=14)\end{array}$ & $\begin{array}{l}\geq 18.5 \text { and }<25^{*} \\
(\mathrm{n}=263)\end{array}$ & $\begin{array}{l}\geq 25 \text { and }<30 \\
(n=183)\end{array}$ & $\begin{array}{l}\geq 30 \text { and }<40 \\
(n=106)\end{array}$ & $\begin{array}{l}\geq 40 * \\
(\mathrm{n}=20)\end{array}$ & \\
\hline One previous caesarean section rate, \% & 8.6 & 8.4 & 11.1 & 13.6 & 21.1 & $<0.001$ \\
\hline Vaginal delivery rate, $\%$ & $\begin{array}{l}50 \\
(n=7)\end{array}$ & $\begin{array}{l}63.5 \\
(n=167)\end{array}$ & $\begin{array}{l}54.6 \\
(n=100)\end{array}$ & $\begin{array}{l}53.8 \\
(n=57)\end{array}$ & $\begin{array}{l}25 \\
(n=5)\end{array}$ & 0.005 \\
\hline Emergency caesarean section rate, \% & $(\mathrm{n}=0)$ & $\begin{array}{l}16.3 \\
(n=43)\end{array}$ & $\begin{array}{l}11.5 \\
(n=21)\end{array}$ & $\begin{array}{l}17.0 \\
(n=18)\end{array}$ & $\begin{array}{l}25 \\
(n=5)\end{array}$ & 0.007 \\
\hline Elective caesarean section rate, $\%$ & $\begin{array}{l}50 \\
(n=7)\end{array}$ & $\begin{array}{l}20.2 \\
(\mathrm{n}=53)\end{array}$ & $\begin{array}{l}33.9 \\
(n=62)\end{array}$ & $\begin{array}{l}29.2 \\
(\mathrm{n}=31)\end{array}$ & $\begin{array}{l}50 \\
(\mathrm{n}=10)\end{array}$ & $<0.001$ \\
\hline
\end{tabular}

*Refers to $\mathrm{p}$ value between the indicated BMI categories.

a normal BMI $\left(\geq 18.5\right.$ and $\left.<25.0 \mathrm{~kg} / \mathrm{m}^{2}\right)$. The mean maternal age in the morbidly obese group was 31.0 years (SD 5.1 years) compared to 29.1 years (SD 5.8 years) in the normal BMI group ( $\mathrm{p}=0.008)$. Only $29.5 \%(\mathrm{n}=28)$ of the morbidly obese were primigravidas compared with the $46.1 \%(n=1,451)$ of the women with a normal BMI $(\mathrm{p}<0.001)$.

In the morbidly obese women, $35.8 \%(n=34)$ had pregnancy-induced hypertension or pre-eclampsia, compared with $9.8 \%(n=309)$ in the normal BMI group $(\mathrm{p}<0.001)$. There were three women with pre-gestational diabetes mellitus. Also, 69 glucose tolerance tests (GTT) were carried out at 28 th week of gestation in the morbidly obese group. In 16 $(23.2 \%)$ cases it was abnormal. We have not compared these results with other groups because an increased BMI is one of the criteria for a GTT. The incidence of fetal macrosomia (birth weight $>4.5 \mathrm{~kg})$ was $6.3 \%(\mathrm{n}=6)$ compared with $1.7 \%$ $(\mathrm{n}=52)$ in the normal BMI group $(\mathrm{p}<0.006)$. In the morbidly obese group the mean birth weight was $3,754 \mathrm{~g}$ (SD $617 \mathrm{~g}$ ) in women with a normal GTT and 3,747 $\mathrm{g}$ (SD $645 \mathrm{~g}$ ) in those with an abnormal GTT. Tables 1 and 2 outline the obstetric outcomes between the different BMI categories.

\section{Discussion}

We found that maternal morbid obesity complicated $0.6 \%$ of pregnancies, compared with $0.4 \%$ in a previous large prospective study from Sweden in 1992-2001 [5]. These figures may possibly be under-reported as in our study the height was selfreported, and it is not clear from the Swedish study how the BMI was calculated.

We have recently shown that BMI calculations based on self-reporting leads to under-reporting of obesity in $5 \%$ of women. As the women tended to either under-report their weight or over-report their height [7]. Furthermore, $22 \%$ of women were misclassified by BMI category when self-reported BMI was compared with digital measurement. Surprisingly, many of the studies to date on obesity and pregnancy do not report the method of BMI calculation or are based on selfreported measurements $[6,8]$. As a result, pregnant women who are potentially at high risk may be categorised as low risk.

The high incidence of gestational diabetes mellitus in our study is alarming, and it is disappointing that our study found that one third of the women did not have a GTT. Of the 188 
women in the Gulf State study [6], 24 (12.8\%) had pre-existing diabetes mellitus and $44(23.4 \%)$ developed gestational diabetes. Our normal practice is to screen for diabetes at 28th week of gestation in obese women. In the light of this study, we believe consideration should be given to screening the mothers when they book for antenatal care in early pregnancy and repeating the screening early in the third trimester if the first GTT is normal. Early diagnosis of gestational diabetes should decrease the incidence of macrosomia and its complications.

The higher incidence of both pre-eclampsia and gestational hypertension in our study is similar to findings of other studies, for example, from Sweden [5], United Arab Emirates [6] and the USA [9]. In general, the severity of pre-eclampsia is related to the severity of obesity although the exact mechanism is uncertain [10]. Both obesity and pre-eclampsia are associated with oxidative stress and an increase in inflammatory markers [11]. Patients with morbid obesity have very large arm circumference with short upper arm length [2]. Larger adult cuffs, therefore, should be available for the accurate antenatal measurement of blood pressure in morbidly obese women.

The increased induction rate in morbidly obese women is partly due to the higher incidence of diabetes and pre-eclampsia. Higher BMI in the first trimester has also been associated with a lower chance of spontaneous labour at term which may lead to more inductions for post-date pregnancies [12]. There is no evidence, however, that induction for a suspected big baby in an otherwise uncomplicated pregnancy is beneficial [9]. A caesarean section for a failed induction is more hazardous for a morbidly obese woman compared with women who are not obese because the risks of infection, thromboembolism and anaesthetic complications are high [13].

The women who were morbidly obese had a high caesarean section rate $(45.3 \%)$ which is in keeping with other reports [14-16]. This was partly due to a higher incidence of previous caesarean section and also a lower incidence of attempted vaginal birth after caesarean section in the morbidly obese women. Unfortunately, BMI calculations from previous pregnancies were not available, but these results suggest that the first caesarean section has even greater long-term obstetric implications for obese women than for non-obese women. In an American study [17] the success rate for vaginal delivery for morbidly obese women with a prior caesarean delivery was only $15 \%$, compared with $25 \%$ in our study, although the numbers are small. A repeat caesarean section in the morbidly obese poses considerable challenges not just for the women but also for the obstetrician and anaesthetist responsible for her care.

We report our findings because they highlight the magnitude of obstetric risks in morbidly obese women and because the evidence suggests that more and more morbidly obese women will be presenting to our antenatal services. We believe that this group of women, which can be easily identified, require a more focused approach to their obstetric care then they have hitherto received.

\section{Disclosure}

The authors have no potential conflicts of interest to disclose.

\section{References}

1 Barry S, Fattah C, Farah N, Broderick V, Stuart $\mathrm{B}$, Turner MJ: The growing challenge of maternal obesity. Ir Med J 2008;1:5-6.

$>_{2}$ Pickering TG, Hall JE, Appel LJ, Falkner BE, Graves J, Hill MN, Jones DW, Kurtz T, Sheps SG, Rocella EJ: Blood pressure measurements in humans. Hypertension 2005;45:142-161.

$>3$ Bergella V, Baxter J, Chauhan S: Evidence-based surgery for caesarean delivery. Am J Obstet Gynecol 2005;193:1607-1617.

4 Royal College of Obstetricians and Gynaecologists (RCOG): Thromboprophylaxis during pregnancy, labour and after vaginal delivery. RCOG Green Top Guideline No. 37, 2004. www.guideline.gov/ summary/summary.aspx?view_id=1\&doc_id=7683.

$\checkmark 5$ Cedergren MI: Maternal morbid obesity and the risk of adverse pregnancy outcome. Obstet Gynecol 2004;103:219-224.

6 Kumari AS: Pregnancy outcome in women with morbid obesity. Int J Obstet Gynecol 2001;73:101107.
7 Fattah C, Farah N, O’Toole F, Barry S, Stuart B, Turner MJ: Body mass index (BMI) in women booking for antenatal care: comparison between selfreported and digital measurements. Eur J Obstet Gynecol Reprod Biol 2009;144:32-34.

8 Farah N, Fattah C, Barry C, Donnelly V, Rafferty G, Stuart B, Turner MJ: Is the antenatal prediction of fetal macrosomia worthwhile? Ir Med J 2009:(in press).

9 Joy S, Istwan N, Rhea D, Desch C, Stanziano G: The impact of maternal obesity on the incidence of adverse pregnancy outcomes in high-risk term pregnancies. Am J Perinatol 2009;26:345-349.

10 Walsh SW: Obesity: a risk factor for preeclampsia. Trends Endocrinol Metab 2007;18:365-370.

11 Denison FC, Price J, Graham C, Wild S, Liston WA: Maternal obesity, length of gestation, risk of postdates and spontaneous onset of labour at term. BJOG 2008;115:720-725.

12 Andreasen KR, Andersen ML, Schantz AL: Obesity and pregnancy. Acta Obstet Scand 2004;83:10221029.

\footnotetext{
13 Weiss J, Malone F, Emig D, Ball R, Nyberg D, Comstock C, Saade G, Eddleman K, Carter S, Craigo S: Obesity, obstetric complications and caesarean delivery rate - a population-based screening study. Am J Obstet Gynecol 2004;190:1091-1097.

14 Sebire NJ, Jolly M, Harris JP, Wadswoth J, Joffe M, Beard RW, Regan L, Robinson S: Maternal obesity and pregnancy outcome: a study of 287213 pregnancies in London. Int J Obes 2001;25:11751182.

15 Bianco AT, Smillen S, Davis Y, Lopez S, Lapinski R, Lockwood CJ: Pregnancy outcome and weight gain recommendations for the morbidly obese woman. Am J Obstet Gynecol 1998;91:97-102.

16 Chauhan SP, Magann EF, Carroll CS, Barrilleaux PS, Scardo JA, Martin JM: Mode of delivery for the morbidly obese with prior cesarean delivery: vaginal versus repeat cesarean section. Am J Obstet Gynecol 2001:185:349-354.
} 